Valentina Gurozhapovna Zhalsanova, candidate of Sociology,

Leading Researcher of the Department of history, ethnology and sociology of the Institute for Mongolian, Buddhist and Tibetan Studies of the Siberian Branch of the Russian Academy of Sciences Ulan-Ude, Russia valyazhal@list.ru

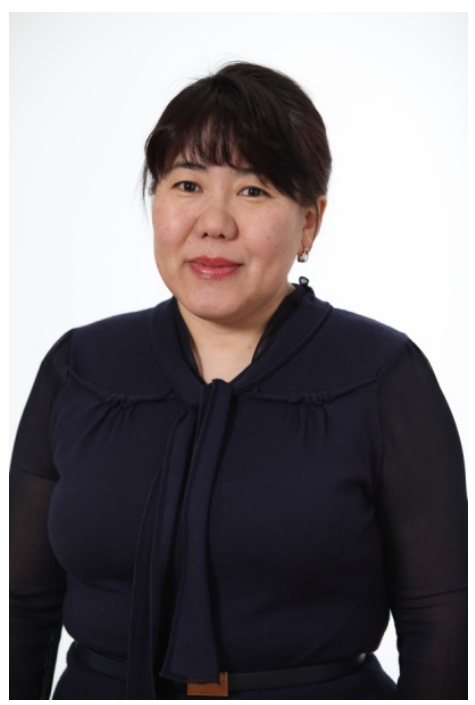

DOI 10.31554/978-5-7925-0571-1-2019-2-201-204

\title{
RURAL MIGRANTS IN THE SUBURBS OF ULAN-UDE ADAPTATION EXPERIENCE AND LIFE STRATEGIES
}

The report is devoted to the analysis of adaptation of rural migrants in the suburbs of Ulan-Ude. The reasons and factors of the relocation of villagers to the city, as well as their future life strategies are studied based on in-depth interviews conducted in 2017 and 2019. The object of sociological research was rural migrants who settled in suburban areas. According to the results of the study, the most numerous group of migrants is represented by socially active immigrants from the village with high adaptive potential. Further life activity of rural migrants is caused by features of social and economic development of Ulan-Ude characterized by prevalence of negative tendencies, first of all, high level of unemployment and low level of salaries. As a result, the formation of a new migration mood in the form of intentions to leave Buryatia for other regions of the country/other countries becomes typical for many rural migrants.

Keywords: Republic of Buryatiya, Ulan-Ude, suburbs, rural migrants, life strategies, adaptation.

Migration processes in the Republic of Buryatia are characterized by the predominance of internal movements from rural areas in the direction of the 
only major urban district of the region - to the capital, Ulan-Ude. Due to the lack of significant agricultural production modern village is unable to solve the problem of employment of many villagers, unable to provide a developed social infrastructure in the form of educational, medical, cultural institutions. Therefore, the main reason for the increasing year-on-year rural-urban migration is the deteriorating socio-economic situation of the majority of rural residents. The state in which the majority of villagers found themselves in the post-Soviet period can be described as deprivation, when there are no conditions and resources to meet the basic social needs characteristic of modern life. One more important reason is the changes in the value structure of the villagers, especially among the younger generation. The attitude to work has changed, dependent moods are growing. Z. I. Kalugina quite rightly notes that "the emerging institutional space, the current economic mechanism distort the value system of the individual, reducing or nullifying the instrumental value of labor in the public sector of agricultural production; rather contribute to social dependency than the development of market standards of behavior and consciousness, depriving the social base of the transformation of the agricultural sector; restrain the process of its modernization" [2000, p. 61]. Therefore, the presence of migration mood and actually the strengthening of migration processes can be explained by the processes that swept the Russian countryside in the post-Soviet period. "Transformation processes against the background of market transformations and democratization of the socio-political sphere have changed the social structure of the population, the image of the village and thus had a negative impact on the quantitative and qualitative characteristics of rural communities. The negative nature of the consequences of social changes has led to the fact that the state of anomie in rural society was deeper than in urban society and led to dysfunctional tension and disorientation of the rural population, the growth of a sense of social alienation because of the monocreality of its space (a narrow market of social "opportunities"). Soviet values, which played a huge role in strengthening the social mechanism, were crossed out. New values that can unite society have not emerged. And most importantly-the sense of social security has disappeared, there are no norms and patterns of behavior that contribute to the formation of long-term life strategies. Tension and disorientation lead to the growth of deviant and delinquent behavior, low level of economic and socio-political activity" [Zhalsanova 2014, p. 60]. 
The rhetoric of most discussions about the village and the social situation of rural residents often refers to the statement of their plight, the increasing degradation and depopulation of villages. Largely agreeing with such views, however, we find it necessary to mention the fact that the migration mood is typical not only for youth but also for people of middle and old age, which is an evidence of the specific adaptive potential of the villagers, irrespective of their socio-demographic characteristics. Moving is a manifestation of courage and a certain activity of people, their readiness for significant changes in lifestyle. That is why, the most numerous type of rural migrants, in our opinion, are socially active people with a sufficiently high level of adaptive potential. It is they who contribute to the mass migration flow, as the whole family moves with them.

The move is the first step in the life of a rural migrant in the new conditions. This period can stretch from several months to several years and depends "on many factors: the availability of housing or the ability to purchase/build it in a short time; employment in the city; the presence of relatives/friends contributing to the arrangement in a new place" [Zhalsanova 2017, p. 176-177]. Despite the fact that the main destination of migration is the city of Ulan-Ude, it should be clarified that its suburbs administratively related to other municipalities-Ivolginsky, Zaigraevsky and Mukhorshibirsky districts of the Republic of Buryatia become the place of residence. This is largely due to the inability to purchase housing in the city, primarily because of the high cost of apartments. Also, it is essential that the suburbs are often a kind of rural life zones which are near the city - a village house (often without sewerage and water supply), the presence of farms in the face of gardens, and somewhere even livestock. Thus, living in the suburbs allows the recent migrant to maintain the usual rural lifestyle, which also contributes to adaptation in a new place, but it does not integrate him/her into the urban space. T. G. Nefedova notes that "the degree of ruralty of the urban population employment is associated with the economic state of the city" [Nefedova 2013, p.25]. Ulan-Ude, despite its status as the main city of Buryatia and the center of all economic life, was unable to provide comfortable living conditions for rural residents.

The success / failure of further adaptation depends on the employment of the villager. The socio-economic crisis has had a negative impact on the labor market in the city as well, there is an increase in unemployment. As a result, rural migrants face a number of vectors for the development of fur- 
ther life strategies: a new migration mood-the desire to move to another region of the country, and/ or to another country; pendulous migration search for work in shifts in other regions/in other countries; strategy of "survival" on the spot in the form of one-time part-time jobs/kalyms or development of personal economy in order to sell products to citizens; disadaptation and further degradation and occurence of deviant and delinquent behavior.

The study once again demonstrates the importance of studying social processes within the suburbs of Ulan-Ude. It is important to understand that the suburbs are not only a territorial entity, but, above all, the people living there.

\section{References and sources}

Zhalsanova V. G. Structurnoye rasseleniye selskikh poseleniy Buryatii [Structural settlement of rural settlements in Buryatia] // Vlast [Authority] . - 2014. - № 6. P. 59-62.

Zhalsanova V. G. Migratsionnoye povedeniye selskikh zhiteley Buryatii: factory I tendentsii [Migration behavior of rural residents of Buryatia: factors and trends] // Chto mi znaem o sovremennykh rossiyskikh prigorodakh: sb. nauch. st. [What do we know about modern Russian suburbs] // ed. by A.S. Breslavsky. - Ulan-Ude: Publishing House BSC SB RAS, 2017. - P. 170-179.

Kalugina Z.I. Transformatsiya agrarnogo sektora Rossii: problemi effektivnosti I adaptatsii naseleniya [Transformation of the agricultural sector of Russia: problems of efficiency and adaptation of the population] // Mir Rossii [The world of Russia]. 2000. - № 3. - P. 48-95.

Nefedova T. G. Desyat aktualnykh voprosov o selskoy Rossii: Otveti geografa [Ten urgent questions about rural Russia: the responses of the geographer]. - M.: Lenand, 2013. - 456 p. 